\title{
间 The Ultrasonography Examination of Fetal Heart Beats as the Application of Mechanic Waves Principle
}

\author{
Esi Luthfiana $\mathrm{AS}^{1, *}$, Afrizal Mayub ${ }^{2}$, Nirwana ${ }^{2}$ \\ ${ }^{1}$ Integrated Islamic High School, Lubuk Linggau, Bengkulu, Indonesia \\ ${ }^{2}$ Graduate School of Science Education, University of Bengkulu, Indonesia \\ Email: esiluthfiana@yahoo.co.id
}

DOI: https://doi.org/10.33369/bjset.1.2.29-37

\begin{abstract}
In this study, a direct observation was carried out on pregnant women in several months of pregnancy by detecting fetal age, fetal length, fetal weight, and normal reactivity of fetal heart beats on ultrasonography. Ultrasonography is a tool that applies the working principle of vibration and waves to the world of health in which mechanical waves that require a medium to propagate. The results showed that the condition of fetal age two to three months in early pregnancy, the transducer on ultrasonography is difficult to detect the weight and length of the fetus. It is mainly because the propagation medium is still tiny, but in conditions of fetal age at four to nine months, the transducer on ultrasonography is able to detect the weight value and fetal length displayed on the ultrasound monitor screen. Therefore, it can be concluded that the working principle of mechanical waves in ultrasonography is one of the developments in physics in the world of technology.
\end{abstract}

Keywords: Ultrasonography, Mechanical Waves, Physical Technology

\section{INTRODUCTION}

The development of science and technology is increasingly being used to obtain convenience. As a result, the development of the IT has an impact on the advancement of various aspects in human life. One aspect affected by the development of the IT is health. An example of the application of the IT in health sector is the use of medical devices that use computer applications, one of which is Ultrasonography (USG). Ultrasonography is a method of choice for early diagnosis of Development Dysplasia of the Hip (DDH) in newborns and infants. It is simple and noninvasive method for visualization of the hip. While treating the DDH, it gives possibility for multiple performances and for monitoring (Pavel, 2013).

Ultrasonography is a medical examination procedure that utilizes the ultrasound waves. Ultrasound waves themselves are sound waves with high frequencies of more than 20,000 cycles per second $(20 \mathrm{kHz})$. These inaudible human waves can be transmitted in the form of beams and can be used for inspection of body network scanning. The ultrasound pulse type used for medical examinations has a frequency range of $2 \mathrm{MHz}$ to $10 \mathrm{MHz}$. The pulse duration is around 1 micronsecond and the pulse repeats around 1000 times per second. Whereas in physics, the term "ultrasound" includes all acoustic energy with a frequency above the human hearing $(20,000$ Hertz), its general use in medical imaging involves a group of frequencies that are hundreds of times higher. 
Ultrasonography could visualize structure the architectural details of soft tissues and organs. The image produced in sonogram is created using a high-frequency sound wave and is displayed as real-time slices of images similar to histological images. High-frequency sound wave $(20 \mathrm{MHz})$ is commonly used in the medical services for dermatological examination. This method is known as dermatosonograpy, while $30-100 \mathrm{MHz}$ was used for eye examination. However, such high-frequency transducer is not available in most medical facilities. The most commonly available transducer in medical facilities are 3-15 MHz transducers that used for obstetrical examination and imaging of other internal organs (Fakhrul Ulum, et al 2017). Appearing in the sonogram of a baby in her mother's womb, it shows the image of the head of a fetus in the womb.

The main benefits of ultrasound examination are non-ionizing radiation, able to distinguish abnormalities / diseases that are solid or cystic, able to measure the volume of tumors or certain organs such as the kidneys, ovaries and uterus. The diagnosis of tumor can be done by triple test approach that is clinical, mammography, and aspiration cytology. Because mammography facilities do not exist in all regions so ultrasonography (USG) can be used as an alternative. Tumor detection through ultrasound image still has the disadvantage that some medical practitioners such as radiology specialist still rely on visual observation in image reading so that only get subjective result so as to make possible mistake in making the diagnosis. A good imaging must be followed by a good image analysis process to obtain an accurate and informative diagnosis. Therefore, we need a computer software system that can identify tumor effectively, quickly, and accurately (Fafi Rahmah, 2018).

Performing diagnostic procedures or therapy can be done with the support of ultrasonography (for example for biopsy or discharge). Usually use a handheld probe that is placed on top of the patient and moved: aqueous gel ensures harmony between the patient and the probe (Figure 1).

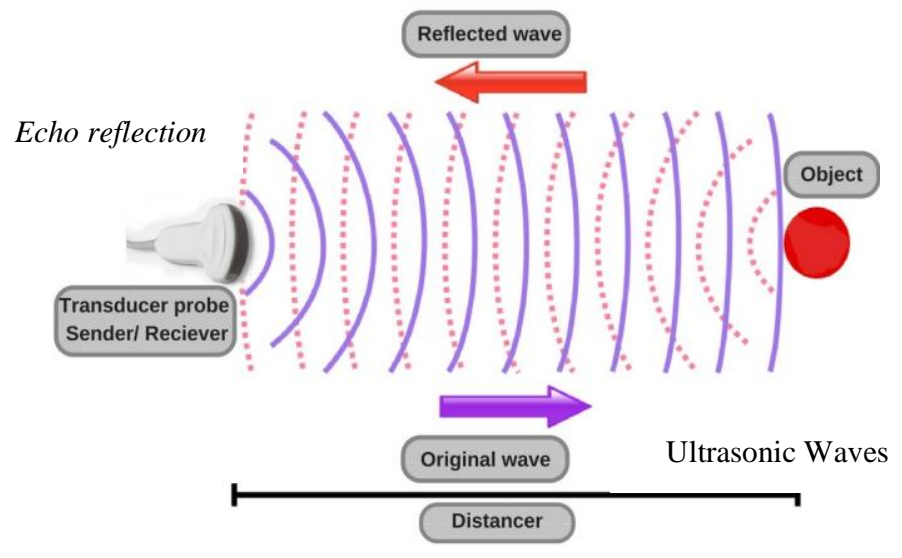

Figure 1. Transducer Work Illustration

Source: prinsiptransduser.com

These reflected sound waves are recaptured by the transducer and passed to the ultrasonic machine, which will calculate the distance of the reflecting network with the probe based on the speed of sound in the network. Then, the ultrasonic machine displays the sound waves reflection on the screen in the form of a signal. The results of the reflection (echo) of the waves are then detected by a transducer which converts the acoustic waves to an electronic signal to be processed 
and displayed on a monitor screen with a greyish or black and white scale image. An ultrasound monitor is a screen that is used to display images from computer data processing, while an ultrasound machine is part of an ultrasound system whose function is to process data received in waves. The ultrasound machine is the center of ultrasound control so that there are the same components as the CPU on the computer, where the ultrasound works to convert waves into images. The machine on ultrasound is used as a data processor.

The sound signal received by the transducer will be converted into an electrical signal and will be sent to the machine. Computers convert electrical signals into image data and reconstruct images, and the processed computer will be then displayed on the monitor. In ultrasound equipment, the monitor screen is one of the media output from the image obtained after an electrical signal from computer processing, and then the ultrasound results are printed with a printer which is the media output of the image obtained from computer processing on ultrasound.

Some terms that we need to know in reading the results of USG (Dewi, 2020) include:

1. GA (Gestational Age): shows the estimated gestational age measured based on the length of the limbs, legs, or head diameter, and detects the development of fetal organs.

2. GS (Gestational Sac): the size of the pregnancy sac, in the form of a black sphere. This usually appears on the results of a first trimester ultrasound photo.

3. CRL (Crown Rump Length): is a measure of the distance from the head to the baby's feet. It is also commonly used by doctors to measure the fetus in the early trimester of pregnancy.

4. BPD (Biparietal Diameter): is the size of the left and right temple which usually used to measure the fetus in trimesters two or three.

5. FL (Femur Length): is a measure of the length of a baby's thighbone.

6. HC (Head Circumferential): is the size of the head circle.

7. AC (Abdominal Circumferential): is the size of the baby's stomach circumference and when combined with BPD they will produce an estimated weight of the baby.

8. FW (Fetal Weight): is the weight of the fetus in the womb.

9. FHR (Fetal Heart Rate): is the baby's heart frequency.

10. LMP (Last Menstrual Period): is the count of the first days of the last menstrual period, and usually used as a reference for the age of the fetus in the womb.

11. EDD (Estimated Delivery Date): is an estimated delivery based on the menstrual date. We may be more familiar with the term HPL (Estimated Birth Day).

An indicator of ultrasound examination of fetal conditions is to determine the fetal heart rate (FHR) in the uterus. Fetal heart rate is one measure that could determine the fetus in a healthy condition or not alive, and the normal examination of the fetal heart rate using ultrasound examination ranges from 120-160 beats per minute (bpm). The gestational age that can be detected by the fetal heart rate (DJJ) through ultrasound recording is at 2 months of gestation (Arif, 2012).

\section{RESEARCH METHODS}

This study was conducted at the Mother Child Hospital (RSIA) Ananda Lubuk Linggau by making direct observations on 20 patients with a classification of 7 patients at 1-3 months gestation, 3 patients at 4-6 months gestation, and 10 patients at 7-9 months gestation. In early pregnancy, most pregnant women are still in a normal condition (feeling happy), where this condition also affects the fetus condition, except in some cases for example the release of blood 
spots during the pregnancy which shows weakness in the womb that can also negatively affect the fetus. In the final months of pregnancy, the $7^{\text {th }}$ month until birth, the fetal heart rate is increasing, and this condition can be displayed on an ultrasound monitor. The scheme of how ultrasound works can be seen in Figure 2.

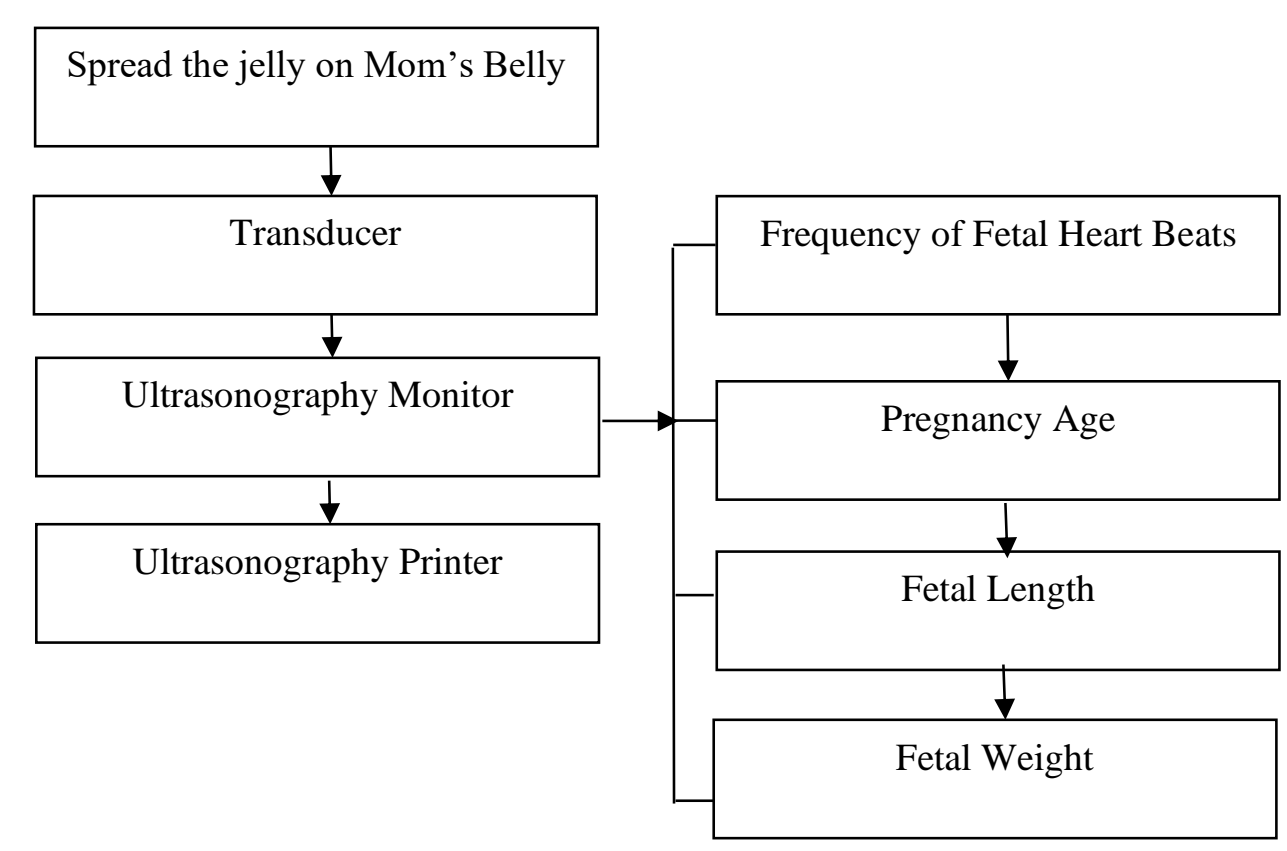

Figure 2. Ultrasonography Working Scheme

Source: Author's Documentation

\section{a. Ultrasound Transducer}

Ultrasonic waves are produced and detected by equipment known as transducers. The transducer on the ultrasound plane functions to convert electrical energy into ultrasound waves that cross the patient's body tissues. This transducer will also receive the reflected ultrasound waves and convert them back into electrical energy. Antika (2017) states that the modality imaging process is started with the pulse ultrasound waves transmitted into the patient then partially reflected ultrasound wave or reflected by the body network creating echo received by the transducer. Inside the transducer, a crystal is used to capture the reflected waves that are transmitted by the transducer.

The received wave is still in the form of an acoustic wave (reflection wave). Hence the function of the crystal is to convert the wave into an electronic wave that can be read by a computer so that it can be translated as an image or displayed on a CRT screen in the form of a greyish- or black and white scale image display (Asriyanto, 2012).

\section{b. Monitor, Machine, and Printer of Ultrasound}

The ultrasound monitor is a screen that is used to display images from computer data processing, while the ultrasound machine is a part of the ultrasound system where the function is to process data received in waves. The ultrasound machine is the center of ultrasound control so that there are the same components as the CPU on the computer, where the ultrasound works to convert 
waves into images. The machine on ultrasound is used as a data processor. The voice signal received by the transducer will be converted into an electrical signal and will be sent to the machine. Computers convert electrical signals into image data and reconstruct images. Then the processed computer will be displayed on the monitor (Figure 3).

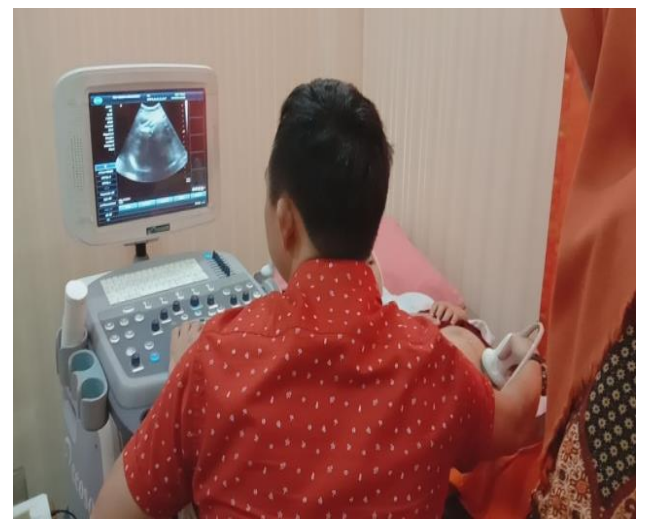

Figure 3. Ultrasonography Examination Process

\section{RESULTS AND DISCUSSION}

Ultrasound imaging exists in a variety of basic images, including the amplitude mode (Amode) explaining the process of the first reflection to occur as a pulse which was sent by the transmitter. A-mode display illustrates the relationship of amplitude of body network depth (Fig.4).

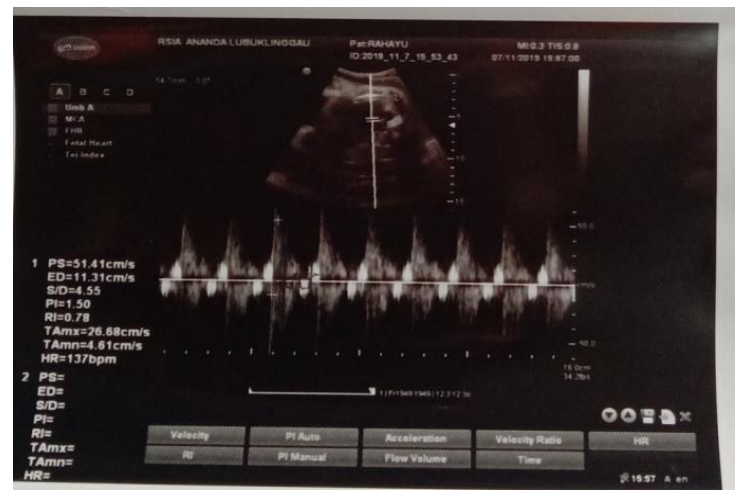

Figure 4. A-Mode Process

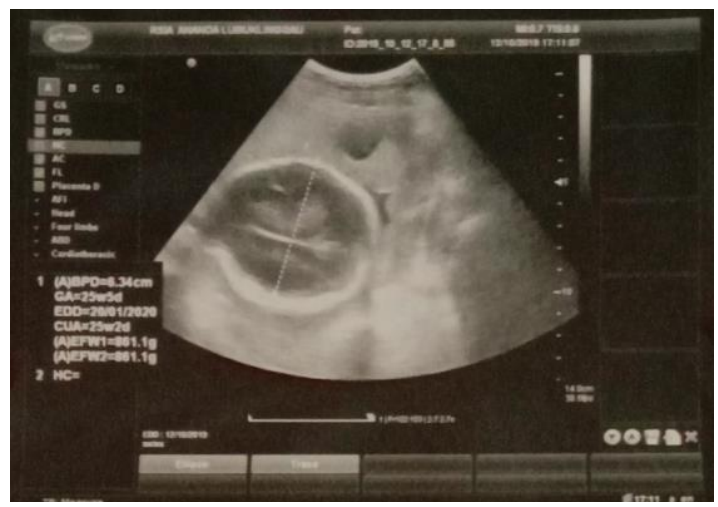

Figure 5. B-Mode Process 
The second, Brightness mode (B-mode) is a mode that the waves echo and amplitude as colors. Color adjusts from amplitude (black, white, grey). This mode is used in sonography. In Bmode ultrasonic, one array is linear of transducers simultaneously scanning an object through the body that can be viewed as a two-dimensional image on the screen (Figure 5). The third is Mmode (Motion mode), where the amplitude and frequency change from one to the XY axis. This diagram is usually specific to heartbeats. This diagram is often seen with B-Mode. M-mode ultrasound is used for certain uses in studying both normal and abnormal heart rate beats. Some examples of ultrasound records categorized as having normal fetal heart rates can be seen from the recording results of Mrs. Rahayu and Mrs. Rian as follows:

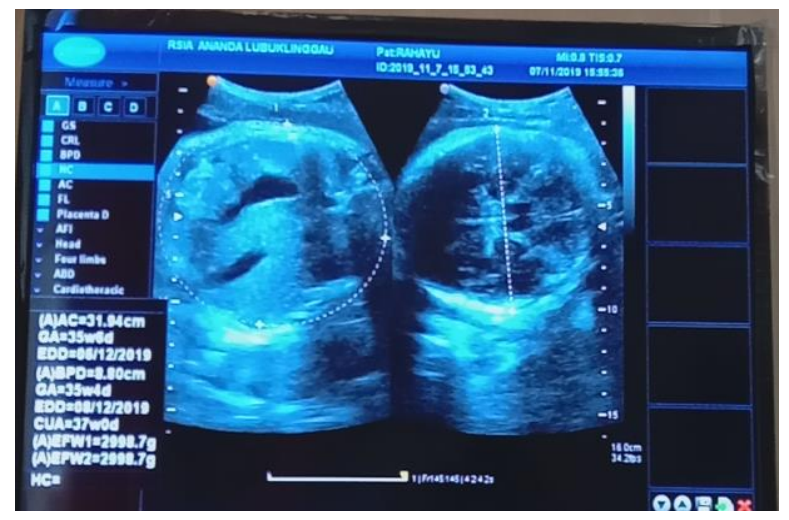

Figure 6. USG Recording Result of Mrs. Rahayu

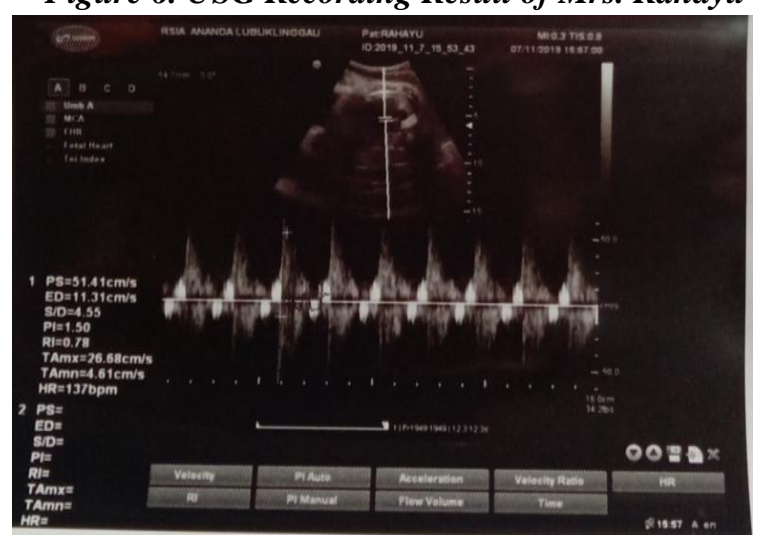

Figure 7 Printed Result of USG Recording of Mrs. Rahayu

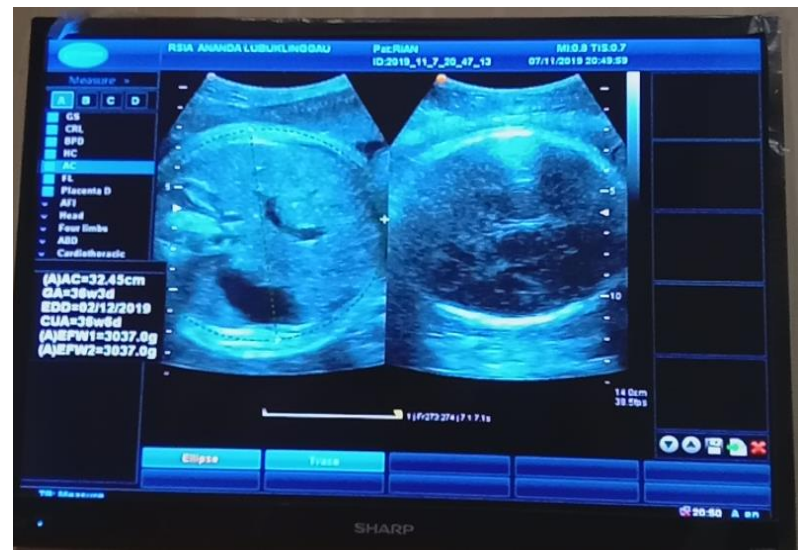

Figure 8. USG Recording Result of Mrs. Rian 


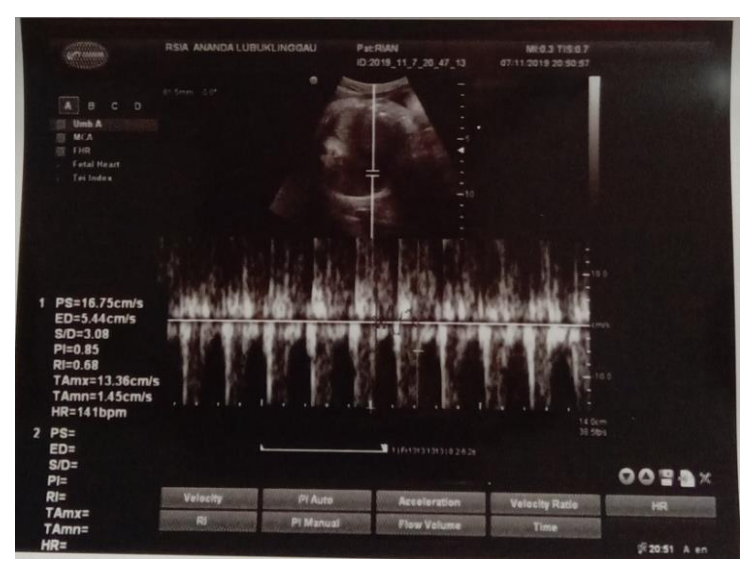

Figure 9. Printed Result of USG Recording of Mrs. Rian

According to the result of ultrasound recordings from Mrs. Rahayu on Figure 6 and Figure 7 shown on the monitor screen and ultrasound printing, it is seen that the condition of the fetus is good. This is observed from the normal fetal heart rate (FHR) about $137 \mathrm{bpm}$, the length of the baby's thigh bone (FL) $7.53 \mathrm{~cm}$, the baby's abdominal circumference (AC) $31.94 \mathrm{~cm}$, the left and right temple (8), $8 \mathrm{~cm}$ and estimated fetal weight (BPD.AC.FL) 2,998 grams at 35 weeks and 4 days fetal age. Whereas in Figure 8 and Figure 9 are the results of Ms. Rian's ultrasound recordings, seen on the screen and the ultrasound print showing that the fetus is in good condition. This is observed from the normal fetal heart rate (FHR) about $141 \mathrm{bpm}$, the length of the baby's thigh bone (FL) $7.27 \mathrm{~cm}$, the circumference of the baby's abdomen (AC) $33.55 \mathrm{~cm}$, the left and right temples (BPD) 9,08 cm and estimated fetal weight (BPD.AC.FL) 3,202 grams at 36 weeks and 6 days fetal age.

The following categories of DJJ wave abnormalities (DJJ values below $130 \mathrm{bpm}$ and above $160 \mathrm{bpm}$ ) are characterized by an imbalance of the generated wave amplitude (not in rhythm). Here are some observations of abnormalities in fetal heart rate we can see from the ultrasound recording of Mrs. Yohana and Mrs. Ayu, as follows:

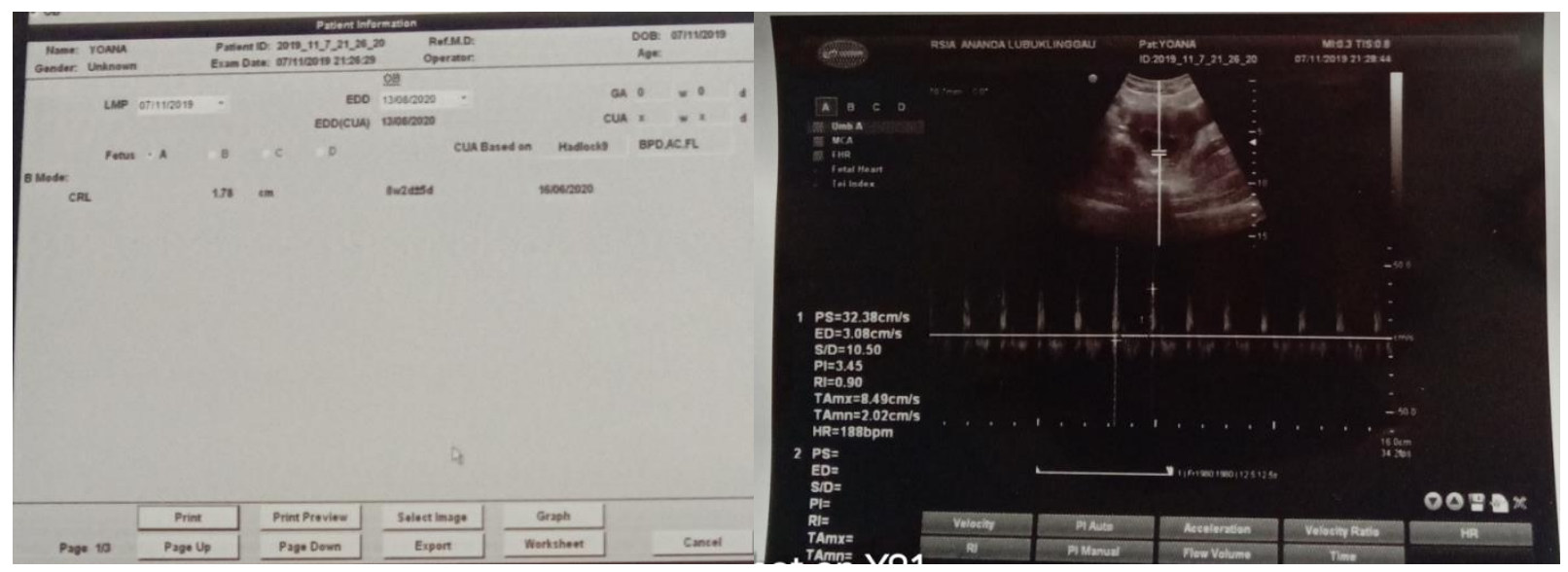

Figure 10.Printed Result of USG Recording of Mrs. Yohana 


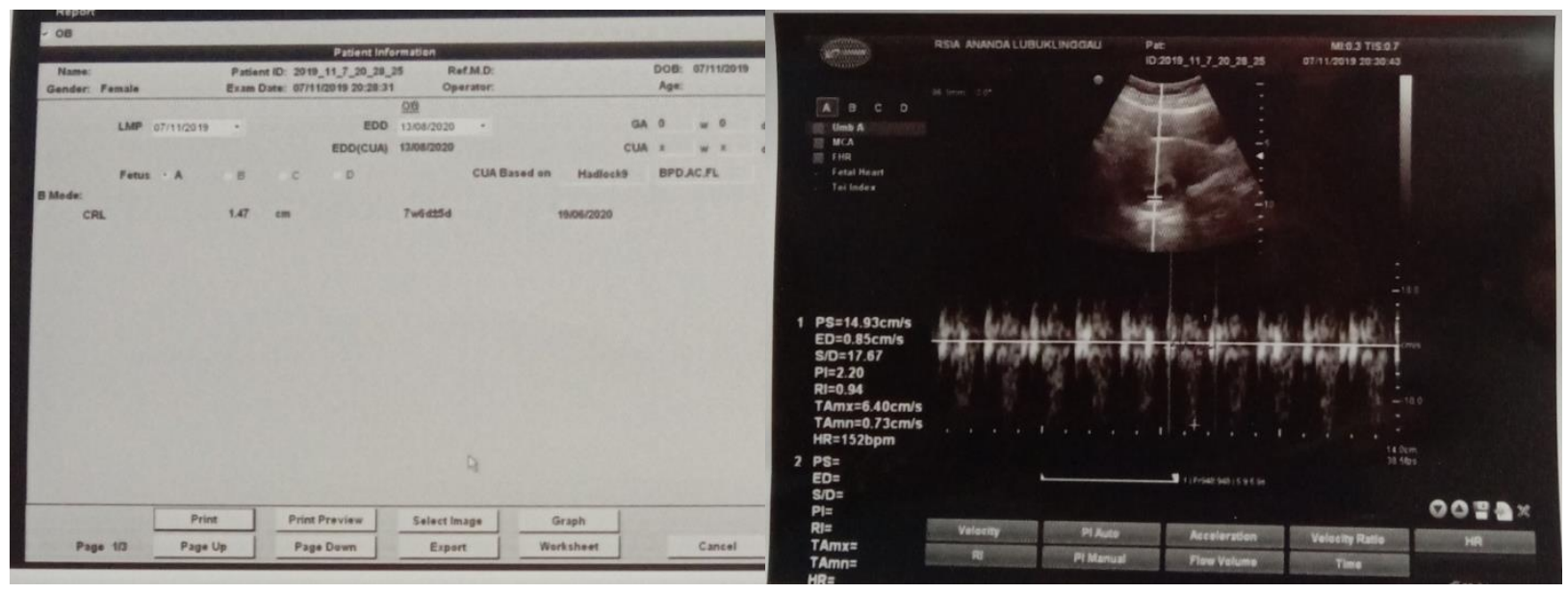

Figure 11.Printed Result of USG Recording of Mrs. Ayu

Figure 10 is the result of ultrasound recording of Ms. Yohana, seen from the ultrasound print showing that the condition of the fetus is very small and there is a pulse abnormality fetal heart. This is observed from the normal fetal heart rate (FHR) around $188 \mathrm{bpm}$, the length of the baby's thigh bone (FL), the baby's abdominal circumference (AC), the left and right temple (BPD) and the estimated fetal weight (BPD.AC.FL) is difficult to detect at 8 weeks and 2 days fetal age. Figure 11 is the result of the USG recording of Mrs. Ayu, and the ultrasound print shows that the condition of the fetus is still too small at 7 weeks and 4 days with normal fetal heart rate (FHR) normal about $171 \mathrm{bpm}$. In addition, the length of the baby's thigh bone (FL), the baby's abdominal circumference (AC), left and right temple (BPD) and estimated fetal weight (BPD.AC.FL) have not also been well detected by ultrasound devices.

\section{CONCLUSION}

Ultrasonography is a tool in the medical world that utilizes ultrasonic waves, which is sound waves that have a high frequency $(250 \mathrm{kHz}-2000 \mathrm{kHz})$. Looking at the functions and workings of ultrasonography, it can be said that the performance of ultrasonography is identical to receiving data in the form of mechanical waves, which in their propagation require a media (intermediary). Therefore, it can be concluded that there is a grouping in observations from ultrasonographic examination (USG), which is in the first condition of fetal age 4-9 months. The ultrasound device can detect fetal age, fetal weight, fetal length, and placental condition because the propagation medium is in the form of lumps (hard), so that the transducer will receive the wave reflection. The results are then displayed on the monitor screen while in the second condition of fetal age 2-3 months the ultrasound device is difficult to detect fetal weight, fetal length and placenta because it is caused by the fetus (as a propagation medium) which is still too small so that the reflected waves are difficult to read by the transducer.

\section{REFERENCES}

Antika, Intan Damaya. (2017). Studi Diagnostik Ultrasonografi Dalam Mendiagnosis Nodul Tiroid Di Rsud Dr. H. Abdul Moeloek Bandar Lampung. Bandar Lampung: Kedokteran Universitas Lampung. 
Arif, Andi Renianti. (2012). Penentuan Kenormalan Denyut Jantung Janin Pada Pemeriksaan Ultrasonografi Dan Fetal Doppler. Makassar: Fisika Medik Universitas Hasanuddin.

Asriyanto. (2012). Analisis Citra Ultrasound Untuk Diagnosis Lesi Payudara. [Tesis]. Jakarta: Fisika Medis dan Biofisika Universitas Indonesia.

Chabibah, Nur., dan Laela, Emi Nur. (2017). Perbedaan Frekuensi Denyut Jantung Janin Berdasarkan Paritas dan Usia Kehamilan, 1-3 ISSN:2089-6778. https://ejournal.poltektegal. ac.id.index.php. Accessed on 6 July 2019.

Damayanti (2012). Asuhan Kesehatan Janin. diunduh 12 Maret 2017. Keliat, B. A. (2015). Keperawatan Kesehatan Jiwa Komunitas.

Dewi, Dinda Silviana. (2020). Cara Membaca Hasil USG dan Waktu yang Tepat dalam Melakukannya. https://tirto.id/cara-membaca-hasil-usg-dan-waktu-yang-tepat-dalammelakukannya-euf8. Accessed on 2 February 2020.

Ionel, Pavel Adrian. (2013). The Importance of Ultrasonography in Early Diagnosis and Treatment of DDH. http://jurnal.medical.aradeanvol.XVI, issue 1-4, 2013, pp.5-10. Accessed on 21 June 2020.

Rahmah, Fafi. (2018). Breast Tumor Detection Using Feature Method on Ultasonography (USG) Imaging. ISSN: 2349-2163. http://doi://10.26562/IJIRAE.2018.MYAE10082. Accessed on 21 June 2020.

Syahrul Imardi, Kalamullah Ramli. (2009). Pengembangan Dan Pengkayaan Fungsi Antarmuka Perangkat Lunak Untuk Visualisasi Dan Analisis Citra Ultrasonografi. http.//ee.ui.ac.id , semtafull > 20101218184834-sm6807-tp4-SyahrulIma-JurnalT. Akses: 20 September 2019

Ulum, M. Fakhrul, dkk. (2017). Ultrasonography of the External Reproductive Organs in Tom. http://doi.org/10.21157/j.ked.hewan.v11i3.5700. Accessed on 21 June 2020.

Yanti, Damai (2017). Konsep Dasar Asuhan Kehamilan. Bandung: PT. Refika Aditama. 